\title{
Law reform and devolution: consultation processes and divorce law in Scotland
}

\author{
BRIAN DEMPSEY ${ }^{1}$ \\ School of Law, University of Dundee
}

\section{Introduction}

$\mathrm{T}$ hat apparently rather modest divorce law reform - the reduction of the length of noncohabitation as a ground for divorce - has proved especially difficult in UK jurisdictions. Despite extensive and costly activity by law reform bodies, governments, parliaments and lobby groups in Scotland, Northern Ireland and England and Wales only Scotland has succeeded in modernising the law in this area. This article critically examines the law reform process begun in Scotland in the late 1980s and carried on after devolution in 1999, with particular emphasis on the central role of consultation and compares the approaches to consultation of three key bodies, namely the Scottish Law Commission (SLC), Scottish governments ${ }^{2}$ and the Scottish Parliament.

The religious-based norm, that marriage should be for life and could only be ended by grave marital fault and not by a decision of one or both of the parties to the marriage remained dominant in Scotland from the Reformation in 1560 until the Divorce (Scotland) Act 1976 brought to Scotland the same compromise between fault and non-fault grounds that England and Wales had introduced by way of the Divorce Reform Act 1969. ${ }^{3}$ The 1976 Act provided that divorce could be granted where a marriage had "broken down irretrievably" if, but only if, adultery, intolerable behaviour, desertion, or separation of two years with consent of the other party, or five years without such consent were proved. ${ }^{4}$

1 My thanks to Professor Peter McEleavy and Edward Dempsey for their helpful comments and also to the anonymous peer reviewer for comments which led to significant improvements in this article. The views expressed and any errors are the responsibility of the author.

2 The first two governments, Scottish Labour and Scottish Liberal Democratic (LibDem) coalitions, were styled "Scottish Executive" while the third, a minority SNP administration, adopted the title "Scottish government". For clarity, the term government is used throughout.

3 For a brief authoritative overview of the history of divorce in Scotland see E Clive, The Law of Husband and Wife in Scotland 4th edn (Edinburgh: W Green 1997), ch. 20.

4 The five fact situations which established the single ground of irretrievable breakdown will be referred to as the grounds for divorce. 
This compromise between fault and non-fault was criticised from the inception of the Act. ${ }^{5}$ Indeed, former SLC chairman, Lord Hunter, has stated that, even as the 1976 Act was being passed, there was a feeling that the thinking behind the compromise was "obsolescent" but the difficulty in finding time for any Scottish measures in the UK Parliament meant that pressing for more appropriate reform would delay matters for many years. ${ }^{6}$

In 1988 the SLC, prompted by demands for similar reform in England, ${ }^{7}$ consulted on the more radical, and arguably more honest and modern, option of a single non-fault ground of divorce following a short period of notice or a short period of separation. As we shall see, despite strong support for abolition of "fault", the SLC instead recommended the reduction of the non-cohabitation periods from two and five to one and two years, in the interests of reducing acrimony and allowing people to "move on" in their lives, something of particular importance, it was said, to any children of the family. ${ }^{8}$ It would take 17 years and four more consultation exercises to introduce this modest reform in Scotland.

In contrast, the even more modest reforms proposed for Northern Ireland in the Family Law (Divorce etc.) Bill 2002, which would have retained the two-year non-cohabitation with consent period but reduced the five-year without consent to three years, were lost when the Northern Ireland Assembly was suspended between 2002 and 2007. That Bill was not "marriage saving" but sought to "encourage good post-divorce relationships between the parties and between them and their children, by encouraging agreement".?

While reform was stalled elsewhere in the UK, the proposals for a non-fault-based law of divorce for England and Wales were progressed as far as legislation. ${ }^{10} \mathrm{Had}$ the relevant part of the Family Law Act 1996 come into force it would have abolished the three fault grounds and provided for divorce exclusively on the basis of a period of separation and reflection. Such reform may seem surprisingly progressive for a "back to basics" Conservative government but the Act was in fact strongly "pro-marriage" as the courts would have been required to have regard to the principles that "the institution of marriage is to be supported" and encourage parties to "take all practicable steps . . . to save the marriage". ${ }^{11}$ Following the failure of a pilot study, due to the cost of compulsory mediation and resistance of parties to the process, the provisions were not brought into force. ${ }^{12}$

Where successive Conservative governments failed to legislate for Scotland in this area between 1989 and 1997, the newly elected New Labour government initiated moves to reform in 1999 which would lead to legislation in the new Scottish Parliament to give effect to the SLC's 1989 recommendations. The focus on the role played by the consultation

5 W A Wilson "Divorce for abracadabra" (1976) SLT 27. Clive took the view that the Act only "pretended to make irretrievable breakdown the sole ground of divorce" and was in fact concerned with the five more readily establishable factual tests rather than whether the marriage had in fact broken down, Clive, Husband and Wife, n. 3 above, 20.003. Such compromises are, however, at the heart of modern family law, J Dewar, "The normal chaos of family law" (1998) 61 MLR 467.

6 Lord Hunter, "Law reform; the Scottish Law Commission" (1988) JR 158, p. 174.

7 SLC, The Ground for Divorce: Should the law be changed?, Discussion Paper No 76 (Edinburgh: SLC 1988), p. 1.

8 SLC, Report on Reform of the Ground for Divorce, Report No 116 (Edinburgh: SLC 1989).

9 Explanatory and Financial Memorandum available at http://archive.niassembly.gov.uk/ legislation/primary/2002/niabill1_02-efm.htm (last accessed 8 June 2012).

10 For an exploration of the reasons legislation was pursued in England and Wales, see E Hasson, "Setting a standard or reflecting reality?" (2003) 17 International Journal of Law, Policy and the Family 338.

11 S. 1(a) and (b). For the Act as a means of imposing the concept of a "good divorce", see H Reece, Divorcing Responsibly (Oxford: Hart 2003). Dewar notes the Act sought to promote two objectives simultaneously by seeking "both to give the parties greater autonomy while at the same time seeking to influence how they use it", Dewar, "Normal chaos", n. 5 above, p. 476.

12 See J Eekelaar, Family Law and Personal Life (Oxford: OUP 2006), pp. 19-21. 
process in law reform allows analysis of its importance as a tool of legitimation over a period of time in which devolution was intended to facilitate more legitimate law reform. The reform of the grounds for divorce has been selected as an appropriate focus for four main reasons. First, it is a very simple change in legislative terms (and so the specific mechanism for the change is unlikely to be controversial). Secondly, this area involves a legislative change that has also been mooted or attempted in both England and Wales and Northern Ireland so that conclusions reached will also have some resonance in these jurisdictions. Thirdly, it allows scrutiny of the law reform activities of all three main players - the SLC, the Scottish governments and the Scottish Parliament - and examines stated aspirations that devolution would improve the law-making process and engage "the authentic voice of Scotland ... of non-aggregated opinion". ${ }^{13}$ Lastly, as we shall see, this apparently modest legislative change provoked a considerable degree of reaction, the impact of which on the law reform process raises important issues for all societies.

\section{The Scottish Law Commission}

The SLC, ${ }^{14}$ like its English counterpart the Law Commission (LC), ${ }^{15}$ was established in 1965 as part of the incoming Labour government's commitment to the professionalisation of law reform. ${ }^{16}$ Commissioners are appointed by the Scottish Ministers ${ }^{17}$ and have a statutory duty to keep under review, and to modernise, the law of Scotland. As early as December 1966 the government invited the SLC to consider reform of the law of divorce in the context of the LC's earlier report Reform of the Grounds of Divorce - The field of choice. ${ }^{18}$

From their inception, fears were expressed that the commissions might usurp executive functions but in the event "constitutional propriety" was maintained with the Cabinet and individual ministers responsible to Parliament for law reform proposals and the commissions in the role of advisors. ${ }^{19}$ Indeed, there is no duty placed on the Lord Advocate or other Scottish Ministers to respond to the recommendations of the SLC, let alone implement them. ${ }^{20}$

Despite their role as mere advisors, many commentators have found "difficulty in explaining what mandate the commissioners have to recommend change in the law affecting

13 D Arter, "From 'spectator democracy' to 'inclusive democracy'? The peripatetic Scottish committees as linkage” (2006) 16 Regional and Federal Studies 239, p. 252.

14 See, generally, Stair Memorial Encyclopaedia, vol. 22, 'Sources of law (general and historical)', paras 623-704; Lord Hope, "Do we still need a Scottish Law Commission?" (2006) ELR 10; Lord Hunter, "Law reform", n. 6 above; and N Brotchie, "The Scottish Law Commission: promoting law reform in Scotland" (2009) LIM 30.

15 See e.g. S Cretney, "The politics of law reform - a view from the inside” (1985) 48 MLR 493; S Cretney, "The Law Commission; true dawns or false dawns" (1996) 59 MLR 631; M Zander, The Law Making Process (Cambridge: CUP 2004), ch. 9 "The process of law reform"; and more recently Hon. Mr Justice Etherton, "Law reform in England and Wales: a shattered dream of triumph of political vision?" (2008) 73 Amicus Curiae 3 (my thanks to Alan Page for this reference).

16 Cretney, "Politics of law reform", n. 15 above, p. 493.

17 Law Commissions Act 1965, s. 2(1).

18 SLC, Divorce: The grounds considered Cmnd 3256 (Edinburgh: SLC 1967)

19 Cretney "Law Commission", n. 15 above, p. 641.

20 It is perhaps surprising how often this constitutionally correct position is lamented, with repeated complaints that government is "failing" to implement proposals of the commissions. For a robust if not entirely convincing rebuff, see Lord Rodger, "The bell of law reform" (1993) SLT 339 and for an overview see P M North "Law reform: process and problems" 1985 [101] LQR 338, pp. 351-5 and the references therein. The current chair, Lord Drummond Young, has on a number of occasions expressed concern at the rate of implementation of SLC reports by the Scottish government especially in relation to civil matters, though he notes "with satisfaction that the Scottish Ministers have put into practice their agreement to respond to our reports within a period of three months": SLC Annual Report (Edinburgh: SLC 2010), p. 7. 
their fellow citizens' lives". 21 This is especially so when the commissions stray beyond the tidying-up of somewhat technical matters (so called "lawyers law") 22 to consider socially contentious areas such as divorce law. ${ }^{23}$ However, I would take the view that it is precisely because family law involves disputes over moral and social values and the legal regulation in that area may be the inherently "contradictory, disordered, incoherent and, in part at least, antinomic" 24 that an informed "professional" view of legal regulation is required. Such contested areas of law require more than what Elaine Sutherland has characterised as Scottish governments" somewhat shallow "conversational law reform" approach which she compared unfavourably with the coherent and comparative SLC approach which provides a well-researched and reflective result. ${ }^{25}$

One answer to the question of the legitimacy of unelected commissioners recommending reform is the consultation process. ${ }^{26}$ As we shall see, at least in relation to this reform process, it cannot be argued that the SLC failed to be swayed by the responses of powerful political interest groups but it would be difficult to assert with any validity that its resulting recommendations took proper account of popular opinion.

\section{THE SLC DISCUSSION PAPER}

I have explored the SLC's 1988 discussion paper The Ground for Divorce: Should the law be changed?, the positions adopted by respondents and the reaction of the SLC to these responses in depth elsewhere. ${ }^{27}$ Although the paper clearly sought to influence the debate, ${ }^{28}$ the arguments for and against each anticipated position were fairly rehearsed. The consultation document ranged very broadly over a host of possible negative and positive aspects of the Divorce (Scotland) Act 1976, asking whether there was a case for reform at all and specifically if "no fault" divorce based solely on a period of either separation or notice would be acceptable. Various periods from three months up to a maximum of a year were suggested as possibilities by the SLC. While no specific proposal was made to abolish the periods of separation of two and five years, the strong possibility that these were

21 Cretney, "Law Commission", n. 15 above, p. 654.

22 Work that even the commissions' least enthusiastic reviewers acknowledge as important, e.g. D M Walker, "The Scottish Law Commission under review" (1987) Statute Law Review 115, though political decisions may be required even within "apparently anodyne" areas of reform, Cretney, "Politics of law reform", n. 15 above, p. 497.

23 These concerns are more commonly articulated in relation to the LC which has had slightly more difficult relations with government than appears to be the case with the SLC, see e.g. Hunter, "Law Reform", n. 6 above, p. 159. The SLC has also been spared the ill-informed attacks of the tabloid press which befell the LC over its recommendation to extend domestic violence protection to cohabiting couples in 1992, Cretney, "Law Commission", n. 15 above, pp. 632-3.

24 Dewar, "Normal chaos", n. 5 above, p. 468, but cf. M Henaghan, "The normal order of family law" (2008) 28 OJLS 165.

25 E Sutherland, "The future of family law reform" (2001) 50 March Family Law Bulletin 2. See also E Sutherland, "What has a decade of devolution done for Scots family law?" in B Aitken (ed.) International Survey of Family Law 2009 (Family Law: Bristol 2009).

26 E.g. North "Law reform", n. 20 above, pp. 338-9; Cretney, "Law Commission", n. 15 above, p. 655; and Cretney "Politics of law reform", n. 15 above, p. 504. Lord Scarman, first chair of the LC, considered the consultation paper "the greatest contribution to the public life of the nation made by the Commission" which subsequent governments "borrowed", quoted in North, "Law Reform", n. 20 above, pp. 338-9. However, North, a former English law commissioner, is "highly sceptical" as to whether any legitimate purpose is in fact properly achieved: ibid. pp. 339-46.

27 B Dempsey, "The difficulty of reforming divorce law" (2009) JR 1.

28 For example, those reading the discussion paper are advised that divorce after a short period of separation is not "easier" merely "more quickly available" and that the divorce process "is not a punishment for having failed in marriage": SLC, Discussion Paper, n. 7 above, p. 10. 
overlong and encouraged conflict by making fault-based divorce more attractive was articulated and a move to a much shorter period of either separation or mere notice contemplated. 29

According to my classification, responses were received from seven family interest groups, seven women's groups, five religious groups, the Scottish Humanist Council, 15 lawyers or legal groups and three advice/support organisations. As we shall see, this is a broadly similar number and range of organisational responses as would be received by the later Scottish government and Scottish parliamentary consultations.

An immediate difficulty for the SLC was the startling range of views expressed not only by organisations in different categories but even between those with similar remits and experiences. ${ }^{30}$ For example, on the specific question of whether or not to retain fault as a ground, seven legal groups or organisations supported retention and seven supported abolition; four family interest groups supported retention and three abolition; and two women's groups supported retention of fault with seven calling for abolition. Only the religious groups appear relatively coherent with all five advocating retention of fault but even here there was division on whether it should be made the sole ground.

This reflects the profound dissensus on the appropriate role of legal regulation of divorce and the underlying values this should reflect. Many respondents passionately urged proposals ranging from divorce on demand at a registry office to returning to scripture and denying divorce even in the face of violence. Reform, it was argued, should promote the presumed interest of society in upholding marriage and make the securing of divorce other than "easy"; promote equality between the spouses; protect children; promote conciliation; provide a public forum in which to validate individual's feelings of anger and/or make divorce as easy as possible. As Cretney amongst others has pointed out, the views of competing interest groups which inevitably reflect value judgments are no sound basis for decisions. 31

Despite coverage of the consultation in the media, only 25 responses from individuals were received. 32 These expressed widely divergent opinions covering the full range of reform options, were often written in highly subjective terms and show no signs of having been produced by any form of organised campaign, a position that would change radically by the time of the second Scottish government consultation in 2000. The SLC did, however, receive a three-page petition with 76 signatures which expressed disapproval of the SLC seeking to erode "the legal and moral institution of marriage" 33 which was perhaps a precursor of things to come.

In an unusual development, the SLC commissioned a public opinion survey which revealed that the overwhelming majority supported abolition of fault as a ground, although opinion was split on what non-fault ground should replace it. ${ }^{34}$ While only 21 per cent of all respondents opposed any change, 63 per cent supported separation, notice or both as

29 The information on the SLC's consultation is taken from Dempsey "Difficulty of reforming divorce law", n. 27 above, unless otherwise indicated.

30 A number of responses were somewhat muddled and self-contradictory while others admitted that there was no consensus within their membership.

31 Cretney "Politics of law reform", n. 15 above, p. 506.

32 See SLC, Report, n. 8 above, pp. 22-3.

33 Ibid. pp. 23-4. This was probably organised by the Cupar Baptist Church, see Dempsey, "Difficulty of reforming divorce law", n. 27 above, pp. 19-20.

34 On the practical difficulties in the use of opinion polls and therefore the rarity of their use by commissions, see Cretney, "Politics of law reform", n. 15 above, pp. 505-6. 
ground(s) for divorce: of those with personal experience of divorce, 76 per cent supported abolition of the fault grounds. 35

\section{THE SLC'S REACTION}

The SLC responded to the confusion of the consultation responses and the clear public support for abolition of fault by recommending that fault be retained. This approach appears to require that improvement of the law achieve some undeclared "super majority" of support. ${ }^{36}$ While those in support of abolition of fault were certainly not unanimous on what single ground should be introduced or in their reasons for supporting reform, equally those who supported retention of fault did so on very different, sometimes mutually contradictory, bases. But those who advocated retention of fault won, despite the SLC acknowledging the substantial support for abolition of fault and that it was unconvinced by many of the arguments put forward for retention. ${ }^{37}$ The SLC was of the view that the varied opinions of opponents of reform had to be "taken fully into account" and concluded that too much controversy would be generated by certain interest groups if fault were abolished. 38

However, the SLC noted that the "vast majority" of respondents supported reduction in the non-cohabitation periods, whatever their views on other matters, and so recommended the admittedly "modest" proposed reform that the periods of separation be reduced from two years with and five years without agreement to one and two years respectively. In so doing it hoped that the damage that fault-based divorce did would be ameliorated and that its suggestion would meet with "general support from a broad middle band of responsible opinion". 39 Qualifying as being of "responsible opinion", and supporting the SLC's somewhat "pusillanimous" proposals, ${ }^{40}$ were therefore somehow intimately linked in commissioner's minds.

There is an obvious argument that decisions on such matters as acceptability of reform to entrenched interest groups should be left to elected politicians: appointment as a law commissioner is not subject to public approval, commissioners have no constituents who can lobby them and present information that may contradict the views of well-financed and well-organised political interests, and appear even less representative of society than the judiciary and elected politicians. ${ }^{41}$ Perhaps as a result of such considerations, the SLC, at least in this case, favoured a pragmatic recommendation which would produce some improvement without, it thought, creating overwhelming opposition from conservative political forces, rather than recommend the most coherent and arguably most progressive options for reform which on many measures did command majority support.

On the other hand, North rejects the "purist" concept that commissions should "unfailingly and uncompromisingly propose what [they think] to be right" without

35 SLC, Report, n. 8 above, para. 2.10.

36 There is a widely held assumption that there is a need for a "broad base" for any recommendation by a commission, see, eg, Hunter, "Law Reform”, n. 6 above, p. 162; North, "Law reform", n. 20 above, p. 339; Michael Kerr, "Law reform in changing times" (1980) 96 IQR 515, p. 516; and Cretney, "Politics of Law Reform", n. 15 above, p. 497.

37 SLC, Report, n. 8 above, para. 3.2.

38 Ibid. para. 3.4.

39 Ibid. para. 1.3.

40 Editorial, "Divorce - business more or less as usual" (1989) SCOLAG 162.

41 Commissioners are drawn from the senior judiciary, the Bar, and the professoriate of two of Scotland's universities. The SLC gained its first female commissioner when Laura Dunlop QC was appointed to a parttime position in 2009 . 
considering the "general political, implications of any proposal" 42 and producing reports that may be too readily rejected by government because of fear of the reaction of interest groups which may simply be a waste of public money. ${ }^{43}$ It might be that commissions would play a more beneficial role if they proposed a small number of possible reforms, with some indication of which would be most coherent and desirable, and left government or Parliament to worry about considerations of cost or the reaction of interest groups. ${ }^{44}$

Yet, despite the SLC's attempt to appeal to "reasonable opinion", by rejecting a move away from fault its recommendations were not acted on by government. Evelyn Gillan, ${ }^{45}$ drawing on the work of political scientist John Kingdon, ${ }^{46}$ concludes convincingly that while the SLC had addressed the "problem" of arguably outdated divorce law and produced a "policy solution", these two streams could not "couple" with the "political" stream as there was an absence of "value compatibility" between the (modest) progressive reforms advocated by the SLC and the "back to basics" agenda of the then Conservative government. ${ }^{47}$ Such "value compatibility", and hence the opportunity to advance the SLCs reforms, would come about only on the election of a New Labour government at Westminster almost 10 years later.

\section{The Scottish government}

Limited devolution of power to Scotland was one of the most significant constitutional commitments of the incoming New Labour government in 1997. The Scotland Act 1998 created a Scottish government and a Scottish Parliament to which were bestowed wideranging legislative powers, including in Scots private law. ${ }^{48}$

Devolution was intended to make a difference to law-making for Scotland in a number of ways. The most obvious would be the greater opportunity to consider Scottish matters, which often struggled for parliamentary time at Westminster. The limited divorce law reforms enjoyed by England and Wales in 1969 had taken a further seven years to come to Scotland and had seen the failure of no less than seven Private Members' Bills before the 1976 Act was passed. ${ }^{49}$ The SLC's modest proposals to reduce the separation time periods had made no legislative progress at Westminster while the LC's more complex proposals of the same year had been taken forward in the guise of the 1996 Act. ${ }^{50}$ It is perhaps fortunate that the Conservative government of the day had other priorities as Scotland might have had the radical and unworkable "marriage-saving" legislation of the 1996 Act imposed upon it.

To avoid creating a "Westminster writ small", 51 the Scottish Ministerial Code required ministers to ensure a participative approach to development of policy and legislation to

42 North, "Law reform", n. 6 above, p. 347.

43 Cretney, "Politics of law reform", n. 15 above, p. 508.

44 North notes that commissions might indicate alternatives to recommendations they anticipate will face opposition by government, "Law reform", n. 6 above, p.339.

45 E Gillan, Influencing Family Policy in Post-Devolution Scotland: The policy process of the Family Law Bill and the sexual bealth strategy, PhD Thesis, University of Edinburgh 2008.

46 Especially, J W Kingdon, Agendas, Alternatives and Public Policies 2nd edn (New York : Longman 2003).

47 Gillan, Influencing Family Policy, n. 45 above, p. 118.

48 Scotland Act, ss. 28 and 29. See C M G Himsworth and C M O’Neill, Scotland's Constitution 2nd edn (Haywards Heath: Bloomsbury Professional 2009), ch. 5.

49 E Clive "Family law reform in Scotland - past, present and future" (1989) JR 133, p. 137.

50 See Hasson, "Setting a standard", n. 10 above.

51 The wide-spread aspiration for a "better politics" is described in G Jordan and L Stevenson, (2000) "Redemocratizing Scotland, towards the politics of disappointment?" in A Wright, Scotland; The challenge of devolution (Aldershot: Ashgate), especially pp. 171-2. 
reflect "the sharing of power between the people of Scotland, the legislators and the Scottish Government" 52 rather than merely consulting on fixed legislative proposals. ${ }^{53}$ This desire for a more participative legislative procedure had its roots in the "democratic deficit" prior to 1997 when Scotland experienced a series of Conservative governments which were felt by many to be remote and hostile to "Scottish Policy traditions" and for which the Scottish electorate did not vote. ${ }^{54}$ Open and frequent consultation would, therefore, be central to Scottish government practice.

Lardy too has identified Scottish governments" "apparent appetite for the views of the electorate" but cautions that it is far from easy to move from such consultations to "evidence based" policy development. ${ }^{55}$ Scottish governments would consult on the SLC's proposal in relation to divorce law no less than three times between 1999 and 2004 and not only were the same difficulties with developing policy on the basis of irreconcilable consultation responses which the SLC faced repeated in all of these consultations but the political stakes were raised by the instigation of highly organised fundamentalist Christian lobbyists in the 2000 and 2004 consultations in the context of an extraordinary campaign by the same forces against the repeal of "section 28 " in 1999.56

The results of this analysis of the divorce reform process both pre- and post-devolution will support Gillan's conclusion that certain "faith groups" were successful in reframing the basis of debate away from the SLC's focus on appropriate legal regulation of divorce in a modern society, taking account of such issues as power imbalances between spouses and the interests of any children, to a moral discussion about the place of marriage in society. ${ }^{57}$ While it would remain resistant to this political pressure, the government nonetheless was forced to shift its terms of engagement towards the "marriage as gold standard" position thereby allowing the minority fundamentalist faith groups to profoundly influence and change the terms of debate. ${ }^{58}$

\section{IMPROVING SCOTTISH FAMILY LAW (1999)}

With the SLC's considered proposals in hand but some 10 years old, the Scottish Office 59 launched a consultation on family law in early 1999, with the responses to be considered by the new Scottish government following the first Scottish election to be held later that year. The consultation paper, Improving Scottish Family Law, sought views on a whole range of issues from significant innovations such as parental responsibilities and rights for unmarried fathers to somewhat minor technical matters. The approach to divorce law reform is set out

52 The Scottish Ministerial Code, "Key principles", para. 3.1. See also B Thomson, "Access and participation: aiming high" in C Jeffrey and J Mitchell (eds), The Scottish Parliament 1999-2009: First decade (Edinburgh: Luath 2009), p. 46.

53 A Page, "A parliament that is different?", in R Hazell and R Rawlings (eds), Devolution, Law Making and the Constitution (Exeter: Imprint Academic 2005), p. 22.

54 P Cairney, D Halpin and G Jordan, "New Scottish Parliament, same old interest group politics?" in Jeffrey and Mitchell, The Scottish Parliament, n. 52 above, p. 105.

55 H Lardy, "Devolution and democracy" in A McHarg and T Mullen, Public Law in Scotland (Edinburgh: Avizandum 2006), p. 103.

56 The impact of "faith groups" on post-devolution Scotland is explored in M Steven, "The place of religion in devolved Scottish politics" (2007) 58 Scottish Affairs 96.

57 Gillan's study, Influencing Family Policy, n. 45 above, examines the post-devolution development of the policies which would result in the Family Law (Scotland) Act 2006 (including the reduction in the separation periods for divorce) and also those relating to a sexual health strategy for Scotland.

58 E.g. ibid. pp. 93 and 144.

59 The Scottish Office was the Westminster department in charge of Scottish business and was headed by UK government ministers. As many of the New Labour Scottish Office ministers went on to be ministers in the Scottish government, there was continuity of personnel as well as policy and approach. 
here in some detail as it will apply, with only minor changes of tone, to the following two consultations and to the resulting Bill.

The main stated aims were "modernisation" of the law and addressing the interests of children. ${ }^{60}$ The modernising agenda is clear from the opening sentence where "strengthen family life" is situated in the context of progressive "family friendly" employment rights, improved child care and action on domestic abuse. "Modernising" then takes on the hue of promoting the interests of children who benefit most from "secure" families. ${ }^{62}$

It should be noted, however, that "family stability" did not necessarily mean "marriagesaving". Although the government's view was that "two parents offer the best prospects for their children and that stability is most easily found within marriage", 63 the only practical expression of this was a commitment to fund non-compulsory family mediation and support services: while doing nothing to encourage divorce, the aim of any reform "must surely be to enable couples whose marriages cannot be saved to part on fair terms with the least possible acrimony". 64 The disproportionate use of the fault grounds in divorces where children were involved, the government asserted, "increases the likelihood of acrimony" and not only negatively affected the parties but also might "interfere with continued parenting after divorce". 65

In keeping with the aspiration for participative reform noted above, views were sought on a wide range of options. The first was to do nothing either in order to see how the 1996 Act worked in practice in England and Wales or on the view that the Scottish system was already moving away from fault; the second to implement the SLC's proposal to reduce the time periods for non-cohabitation and the third to proceed with something akin to the "radical changes" found in the 1996 Act. ${ }^{66}$

Sixty-one consultation responses addressed the grounds of divorce; a mere eight from individuals and 53 from organisations. ${ }^{67}$ The organisational responses included three local authorities, five children's groups, four family organisations, five counselling or mediation groups, 10 religious groups, and 24 legal organisations, lawyers or legal academics. As with the SLC consultation, there was no consensus of view even within these categories. ${ }^{68}$ The very small number of individual responses and the dominance of legal and religious interests suggest that it was the "usual suspects" who felt entitled or obligated to respond. ${ }^{69}$

60 Equality and protection were also significant aims though these had relatively little specific impact on reform of the grounds for divorce.

61 Scottish Office, Improving Scottish Family Law (Edinburgh: Scottish Office 1999), p. iv.

62 Ibid. p. v.

63 Ibid.

64 Ibid. p. 6. Here we can detect echoes of the 1996 Act, which is understandable given the consultation document was written by ministers in a Westminster government which was, at the time, committed to bringing the 1996 Act into effect. For the 1996 Act, see Reece, Divorcing Responsibly, n. 11 above.

65 The most recent statistics then available revealed that in 1997, where children were present, $12 \%$ of divorces were based on adultery and $57 \%$ on intolerable behaviour compared to $6 \%$ and $17 \%$ respectively where there were no children, Scottish Office, Improving, n. 61 above, p. v.

66 Ibid. pp. 5-6.

67 Some of the responses are available at www.scotland.gov.uk/Resource/0039/00396139.pdf while a summary is available at www.scotland.gov.uk/Resource/0039/00396140.pdf (both last accessed 29 June 2012).

68 For example, of those in the religious groups category, which had been the most consistent group in the SLC consultation, two wanted no reform, one wanted reduction in non-cohabitation periods, six sought radical change similar to the 1996 Act and one opposed all of the options presented.

69 There were possibly fewer responses from family and children's groups than might have been expected and a notable scarcity of e.g. women's groups, father's groups and trade unions. For an overview of "civil society" activity in the UK, including trade unions and religious groups, see S Daly and J Howell, For the Common Good? (London: Carnegie 2006). 
Overall nine organisations favoured no action, 26 favoured reduction in non-cohabitation periods and 16 more radical reform.

\section{PARENTS AND ChILDREN (2000)}

In late 1999 and early 2000 the Scottish government faced what was, at least for Scotland, an unprecedented onslaught in reaction to its plans to repeal the homophobic section 28 legislation which banned promotion of homosexuality and labelled same-sex relationships "pretended families". ${ }^{70}$ The Keep the Clause campaign was well funded and made good use of the media, in particular the best-selling, Labour-supporting tabloid The Daily Record and also a private poll, financially underwritten by Christian businessman Brian Souter, which delivered anti-repeal literature to every household in Scotland. Although section 28 was eventually repealed in the Ethical Standards in Public Life Etc. (Scotland) Act 2001 the pressures placed on the government to draw back from progressive and rational reform in favour of promoting traditional values was profound. ${ }^{71}$

At the height of the Keep the Clause furore the government drafted and then launched its White Paper responding to the 1999 consultation. The paper, Parents and Children, continued the theme of modernisation and responding to the reality of family change and, while the interests of children were still to the fore, the emphasis now shifted slightly towards supporting families through transition. ${ }^{72}$ Although the government acknowledged the importance of marriage to society, it was resolute in not being drawn into a discussion of "the merits of different family styles". 73

As before, there were echoes of the "good divorce" approach found in the 1996 Act but the government revealed that it had rejected both that "radical" option and the status quo. ${ }^{74}$ The government now firmly supported the SLC's proposed reduction in the periods of non-cohabitation as this had been backed by slightly more than half of those who expressed a view in the 1999 consultation. ${ }^{75}$ However, one radical possibility, that adultery might be subsumed within a single ground of intolerable behaviour, was raised for the first time. ${ }^{76}$ This cannot be viewed as an attempted move away from fault but was, rather, a further example of a more rational and modern law as it was not necessarily the mere act of adultery which should found the divorce (after all many marriages survive admissions of adultery) but the fact that the other spouse may find the behaviour intolerable. ${ }^{77}$ While the inclusion of this issue may have been a genuine "modernising" idea which the government must have known would provoke the ire of Christian fundamentalists, especially given the febrile atmosphere created by the Keep the Clause campaign, it can also be seen as a potential lightning rod for conservative respondents; if attacked it could be easily jettisoned

70 See B Dempsey (1999) "Section 28 - the repeal of "vindictive Tory legislation"' (1999) SCOLAG 144-7 and K Armstrong “Contesting government, producing devolution: the repeal of 'section 28' in Scotland” (2003) 23 Legal Studies 205. For the impact of the campaign on individual lesbian and gay people, see e.g. B Cant, Footsteps and Witnesses (Edinburgh: Word Power 2008), p. 111.

71 See the quotes from senior civil servants and politicians at Gillan, Influencing Family Policy, n. 45 above, pp. 139-44, and especially those of Susan Deacon, then Minister for Health and Social Care, p. 141.

72 Scottish Executive, Parents and Children (Edinburgh: Scottish Executive 2000), p. iii.

73 Ibid. p. iii. The paper addressed other contentious issues, including parental responsibilities and rights for unmarried fathers and step-parents and proposals for recognition of unmarried cohabiting couples.

74 Ibid. p. 1.

75 Ibid. p. 17 . Only $15 \%$ had supported the status quo.

76 Ibid. p. 18.

77 The government did not champion the concept but asked for views: in doing so it appears to echo points made by Kenneth Norrie in his submission to the 1999 consultation. 
thus allowing the government to appear accommodating while pressing ahead with the reduction in the periods of non-cohabitation. ${ }^{78}$

The responses to Parents and Children show a number of interesting developments. ${ }^{79}$ The most significant of these was that a large number of responses were submitted by private individuals in response to a sustained campaign against government policy by the evangelical political lobby the Christian Institute (CI). In the face of this, a further development was the classification of responses by the government into "CI" and "nonCI" responses on the basis of the similar wording and the restriction of comments to those issues raised in the CI campaign.

The government identified 160 individual responses and six organisational responses as resulting from the CI campaign. All of the individual responses asserted the writer's opposition to the government's supposed intention to make divorce "easier" and to "equate" marriage and cohabitation as undermining marriage. ${ }^{80}$ These submissions rarely acknowledged that they were in response to the CI campaign nor did they display any familiarity with the content of the consultation document. The source and nature of these individual responses hardly suggest that devolution had resulted in a better engagement of the Scottish public with policy development, at least this early on in the process.

In contrast to the individual responses, the public statements of the CI itself were generally carefully argued and supported by reference to a number of published studies which purported to establish the negative social and individual effects of divorce. ${ }^{81}$ The CI's position was that divorce on non-fault grounds was not acceptable to Christians and it challenged the government's central argument that shorter time periods would lead to a move away from fault grounds and therefore reduce acrimony.

Of the non-CI responses, 10 were from private individuals and 44 from organisations or professionals. While the number of individuals had not increased, and many of the organisational respondents were the same ones who replied to the earlier consultation, ${ }^{82}$ the presence of respondents such as the UK Men's Movement and Families Need Fathers indicates that slightly more than the usual suspects were engaged by this particular exercise.

Yet again, there was no consensus on reform. Fifteen non-CI groups or individuals supported reduction in the periods of non-cohabitation with 11 opposed. On the merger of adultery and intolerable behaviour, 13 non-CI organisations and individuals were in support and 30 opposed. In relation to the merging of adultery into the general intolerable behaviour ground, there was a fairly clear trend so the consultation could be said to have served some purpose, though, as before, this does not answer any question about what values should underpin the legal regulation of divorce or whether retaining adultery as a separate ground is rational or coherent. In relation to the separation periods, it is difficult to see any benefit in terms of policy development from the results of this consultation.

78 Which, in the event, was exactly what happened.

79 Responses are available at www.scotland.gov.uk/Topics/Justice/law/17867/FLSA2006/13804/Responses and an analysis at www.scotland.gov.uk/Resource/0039/00396142.pdf (both last accessed 29 June 2012).

80 Eric Clive has made the point that marital breakdown comes before divorce, easy or otherwise, and that "[i]t seems likely that more difficult divorces would no more save marriages than more difficult funerals would save lives", Husband and Wife, n. 3 above, 20.014, fn. 44.

81 Christian Institute, Marriage: Worth Fighting For (Edinburgh: Christian Institute 2000).

82 Including 12 religious groups and 16 lawyers or legal groups. 


\section{FAMILY MATTERS (2004)}

The impact of the CI intervention in the 2000 consultation, linked with the profoundly politically uncomfortable experience of the Keep the Clause campaign, was responsible in large part for there being no legislative progress on reform of divorce law, or other progressive family reforms, for a number of years. ${ }^{83}$ In the 2003 Scottish election campaign, several Christian political groups targeted progressive MSPs who had supported repeal of section 28 but their challenge proved unsuccessful. ${ }^{84}$ The election resulted in the formation of another Labour/LibDem coalition and that government issued what would be a final consultation, the 2004 White Paper Family Matters, which closely resembled the previous papers by emphasising the best interests of children within a clearly articulated agenda of meeting the needs of "all of Scotland's people". 85 The reductions in the time periods of non-cohabitation were now "firm proposals", though the government invited people to "record" their views if they so wished. 86 The possibility of merging adultery with intolerable behaviour was not progressed.

While we are told that opposition to the government's proposals among individual respondents outweighed support by 9:1 the responses are difficult to analyse as, from a total of 142, 80 were submitted "in confidence" and so are unavailable for scrutiny. ${ }^{87}$ Individuals may, of course, have legitimate reasons for seeking anonymity but that could be achieved in most cases by redaction thus allowing the content of the response to evaluated. As almost all of these "in confidence" responses were opposed to the government's position and we know from the responses to the 2000 consultation that many of such responses show no indication of their authors having read the consultation document, anonymity makes it difficult for parliamentarians as well as the public to take a view on whether the government gave the appropriate weight to whatever argument there may have been in these responses. What can be said is that these individuals appear not to be representative of the generality of public opinion in Scotland at the time. ${ }^{88}$

Of the 48 organisational responses, 11 were from religious groups, relatively steady in number over the three consultations, and nine from legal groups, legal academics or lawyers, a significant drop from 24 in 1999 and 16 in 2000. The reason for the decline in engagement by legal groups and professionals is unknown but may be related to consultation fatigue or a view that the case for or against reform had been set out several times and that there was a degree of contentment with the likely outcome given that the reduction in noncohabitation periods were now "firm proposals". In any event, on this occasion there was a high degree of consensus with 40 organisations in support of the government's proposals and only eight (seven religious groups and one legal group) opposed.

83 A civil servant involved in family policy at the time is quoted as saying: "The Family Law Bill, I suspect, got put into the long grass prior to the election because you don't want the backlash from the right-wing saying you're in favour of quickie divorces and all the rest of it just prior to an election.", Gillan, Influencing Family Policy, n. 45 above, pp. 140-1.

84 See Armstrong, "Contesting government", n. 70 above, and P Cumper and M Bell "Reforming section 28: lessons for Westminster from Holyrood” (2003) 4 EHRLR 400.

85 Scottish Executive, Family Matters (Edinburgh: Scottish Executive 2004), p. 3. Again it was asserted that the reductions in the periods of non-cohabitation would "not cause divorces", p. 17.

86 Ibid. pp. 16-17.

87 L Nicholson, Improving Family Law in Scotland: Analysis of written consultation responses, p. 20, available at www.scotland.gov.uk/Resource/Doc/26350/0025007.pdf. The responses themselves are available at www.scotland.gov.uk/Publications/2004/10/20073/44798 (both last accessed 1 June 2011).

88 At the time, $47.5 \%$ of Scots indicated that they had "no religion", Gillan, Influencing Family Policy, n. 45 above, pp. 91-2, citing information from the Scottish Social Attitudes Survey 2004. 


\section{OVERVIEW}

Some important differences between the SLC's consultation in 1988 and the first governmental consultation in 1999, on the one hand, and the responses to the two White Papers in 2000 and 2004 have been identified. The most significant of these is the wellresourced intervention by the CI to encourage individuals to oppose the government's reforms in the context of the highly charged campaign against repeal of section 28 . As we shall see below, reference was made by some parliamentarians to the "overwhelming" number of negative responses from individuals to these consultations without addressing the particular circumstances of the CI campaign.

However, the similarities outweigh the differences. Few private individuals were moved to respond other than the unrepresentative group, numbering between 130 and $160,{ }^{89}$ mobilised primarily by the CI. The desire for more participative policy development in a devolved Scotland was intended to move away from "consultation with the 'usual suspects', or the most powerful interest groups". ${ }^{90}$ It is true that latterly a small number of interest groups did come forward to present their views for the first time ${ }^{91}$ but those labelled the "usual suspects", especially generally conservative religious and to some extent legal groups, continued to dominate. 92 This can be seen as a reflection of the "logic of consultation" which tends to favour those organisations with the greatest resources. ${ }^{94}$

The responses themselves continued to be as fundamentally contradictory as those received by the SLC. Based on a self-declared prioritisation of the needs of children, for example, different respondents called repeatedly and emphatically for no change, for reduction in the separation periods and for more radical reform. Those who enter the process with firm views might refine the presentation of their views over time but those who do not have firm answers appear muddled: neither show evidence of developing their positions. The conclusion to be drawn from the government's experience is that conducting repeated consultation on the grounds of divorce, a contentious issue which involves competing interests, does not lead to greater clarity on what the law should be as there is no means to resolve basic conflicts in respect of values.

The hiatus between 2000 and 2004, caused by fears in relation to the 2003 election and the slight increase in acknowledgment that marriage remained an important institution which should not be undermined, suggests a government under pressure. However, throughout this extended process of consultation, the government stood resolute in favour of "modernisation" of the law, aiming, as it saw it, to meet the needs of families as they

89 A fairly modest number given the CI's claim to be supported by "2,300 individuals from across the Christian denominations in Scotland of which 370 are Church leaders", written submission from CI to the Justice 1 Committee available at http://www.christian.org.uk/scotland_archive/familylaw/2005/responsetojustice1 _april05.pdf (last accessed 8 June 2012).

90 Cairney et al., "New Scottish Parliament", n. 54 above. This desire has also affected Westminster, at least in terms of greater "pre-legislative scrutiny", A Brazier, "Pre-legislative scrutiny: a positive innovation" in A Brazier (ed.), Parliament, Politics and Law Making (London: Hansard Society 2004), p. 59.

91 E.g. those associated with the "men's movement", for which see R Collier and S Sheldon, Father's Rights Activism and Law Reform in Comparative Perspective (Oxford: Hart 2006).

92 D Halpin and G Baxter, "Searching for tartan policy bandwagons", available at http:// citation.allacademic.com /meta/p_mla_apa_research_citation/2/7/9/4/4/pages279441/p279441-1.php, especially p. 20, table 7 (last accessed 4 July 2012). However, consultations are open processes and the use of this somewhat derogatory label for those who do consistently take the trouble to respond seems somewhat harsh.

93 Cairney et al., "New Scottish Parliament", n. 54 above, p. 107.

94 For a generally positive review of attempts at "participative democracy", see G Reid "The fourth principle: sharing power with the people of Scotland", in Bernard Crick and Andrew Lockyer (eds), Active Citizenship: What could it achieve and how? (Edinburgh: EUP 2010). 
actually existed and functioned rather than promoting a traditionalist view of marriage. Many individual MSPs would not prove so resilient in the face of lobbying by religious fundamentalists representing the interests of a small minority of Scottish society.

\section{The Scottish Parliament}

With this extended consultation process and the 2003 election behind it, in early 2005 the government introduced the Family Law (Scotland) Bill 2005, clause 10 of which would reduce the non-cohabitation periods for divorce to one year with agreement of the other party and two years without such agreement. The policy memorandum which accompanied the Bill noted that "family life" should generally be a private matter for individual families but, if legal intervention was required, the three principles to be applied were "safeguarding the best interests of children; promoting and supporting stable families [and] updating the law to reflect the reality of family life". 95 Reduction in the non-cohabitation periods was intended to reduce unnecessary conflict and recrimination, especially in cases where children were present. ${ }^{96}$ The government had been able to reject the submissions of those who favoured the "marriage saving" approach of the 1996 Act since implementation had been abandoned in England and Wales as being neither cost-effective nor helpful in reducing acrimony between divorcing parties. ${ }^{97}$

While the question of precedent in the relationship between the SLC and government is clear, the proper relationship between government and Parliament is more contested. As noted above, the architects of devolution sought a power-sharing dynamic involving "the people of Scotland", government and parliamentarians. ${ }^{98}$ The Scottish Parliament was designed to be "a committee-based parliament in the Scandinavian or German mould"99 to provide an effective check on Westminster-style executive dominance, but many commentators have expressed serious doubts as to whether this has been effective. ${ }^{100}$ Page goes so far as to conclude that Scottish governments have been able to exercise a "powerhoarding rather than power-sharing" approach based on their view that "possession of a parliamentary majority brings with it the right to have its wishes translated into law". ${ }^{101}$

While it may be true that the wishes of the two governments prevailed in the majority of cases in the first two sessions of the Parliament, its proposals on divorce would be challenged and, indeed, amended in ways not to its liking. This despite the fact that the lead committee scrutinising the bill, Justice 1, had, as with all committees, a government majority. ${ }^{102}$

\section{THE COMMITTEE}

The process in the Scottish Parliament is that a lead committee is tasked with scrutinising a Bill and reporting in advance of the Bill receiving approval or disapproval of its general principles before the whole chamber (Stage 1). Those Bills which progress are then closely scrutinised (and often amended) during Stage 2 which is conducted by the committee. The

95 Family Law (Scotland) Bill 2005, policy memorandum, paras 3 and 4.

96 Ibid. para. 27.

97 Ibid. para. 30.

98 See nn. 51-5 above.

99 D Arter (2003) "The Scottish Parliament and the goal of a 'new politics': a verdict on the first four years", p. 5, available at www.ecprnet.eu/standinggroups/parliaments/papers/arter.pdf (last accessed 8 June 2012). See also Himsworth and O’Neill, Scotland's Constitution, n. 48 above, pp. 264-70.

100 E.g. C Charman and M Shephard (2009) "Committees in the Scottish Parliament" in Jeffrey and Mitchell, The Scottish Parliament, n. 52 above, pp. 23-5.

101 Page, "A parliament that is different?", n. 53 above, p. 13.

102 The committee consisted of three Labour, one LibDem, two SNP and one Conservative MSP. 
Bill then returns to the whole chamber for Stage 3 where it can again be amended and faces a final vote of approval or disapproval. ${ }^{103}$

To inform its deliberations the committee launched a "call for evidence" on the proposals contained within the Bill, effectively yet another consultation process. ${ }^{104}$ Although this might merely duplicate previous consultations and add to the danger of "overload", 105 the responsibility for this cannot be attributed to the committee itself as the original intention of those who constructed the devolution settlement, that consultations would be undertaken jointly by the government and the lead committee, was not approved in the Parliament's Standing Orders. ${ }^{106}$ Indeed, far from there being pressure not to hold what was effectively another consultation, the fact that any amendments to the legislation made by the committee subsequent to its consideration of this evidence are not then subject to yet another consultation process may leave the amendments open to challenge. ${ }^{107}$

Of the 120 individual responses to the call for evidence that can be scrutinised and which addressed the question of divorce, only one welcomed the proposals. The other 119 responses were similar in tone, structure and content, and, while not acknowledging the CI leaflet as a source, attacked the proposals as undermining marriage by "making divorce easier and quicker". 108 Organisations supported the introduction of a one-year period by 25 to 13 (with 11 of those opposed being religious bodies) and the two-year period by 23 to 15 (with 10 of those opposed being religious groups). The committee then chose to invite oral evidence in public session from seven religious groups, two mediation groups, two children's groups, two legal academics and the Law Society of Scotland, as well as officials and the minister from the relevant department. ${ }^{109}$ The pattern of all the previous consultations, with a lack of consensus reflecting fundamentally competing value judgments and rigorous intervention by particular minority interest groups, was repeated and in fact exacerbated by disproportionate access being granted by the committee to religious organisations.

Based on the opinions presented to it, in its report to Parliament in advance of the Stage 1 debate, the committee's starting position was not specifically the interests of children or of reducing acrimony and allowing people to "move on" but the more conservative aim of striking a balance between not increasing the number of divorces and "recognising the value that the institution of marriage brings", on the one hand, and "not unnecessarily interfering in the private lives of individuals", on the other. ${ }^{110}$ In particular, the majority of the committee were sceptical about the government's claims of reducing

103 Himsworth and O'Neill, Scotland's Constitution, n. 48 above, ch. 8. For full details of the progress of the Bill, see www.scottish.parliament.uk/business/bills/36-familyLaw/36-familyLaw-progress.pdf (last accessed 4 July 2012).

104 The Committee's Stage 1 report on the Bill, with details of evidence submitted, is available at http://archive.scottish.parliament.uk/business/committees/justice1/reports-05/j1r05-08-vol01-01.htm (last accessed 8 June 2012).

105 Page, "A parliament that is different?", n. 53 above, p. 28.

106 B Winetrobe (2004) "Making the law in devolved Scotland" in Brazier, Parliament, Politics and Law Making, n. 90 above, p. 59 .

107 In the Stage 3 debate the minister, Hugh Henry, labelled the committee's Stage 2 amendments "arbitrary" and noted that their favoured periods of 18 months and three years had been "subject to no consultation whatever", OR col. 21768.

108 Justice Committee Report, SP Paper 401, 7 July 2005, para. 37.

109 The committee enjoyed the services of Professor Kenneth Norrie as advisor.

110 Justice Committee Report, n. 108 above, para. 45. The committee expressly recognised "that for a significant section of Scottish society marriage is a life-long commitment and that for some people divorce is intrinsically wrong", para. 46. 
acrimony by shortening the non-cohabitation periods, echoing the view of the CI and others opposed to reform that it was divorce itself that caused acrimony and distress rather than the length of separation periods and that the government had failed to justify its proposed reforms of the non-cohabitation periods. ${ }^{111}$ Despite these particular concerns, the general principles of the Bill, which contained many other provisions, survived its Stage 1 reading 112 and moved to Stage 2.

Although amendments are often made at Stage 2 these generally do not go against government policy as the makeup of the committee reflects the strength of the parties in the Parliament. ${ }^{113}$ An avowedly "marriage-saving" amendment from the Conservative member, Margaret Mitchell, which would have denied divorce unless the pursuer had made attempts at reconciliation, was lost by two votes to four, with the element of compulsion the stumbling block for the majority. ${ }^{114}$ A Scottish National Party (SNP) amendment to retain the two-year period for divorce with consent was lost by just four votes to three. ${ }^{115}$ The failure of these amendments indicates some resistance to the influence of the CI and other fundamentalist religious lobbies. However, to the surprise of many, two further amendments from Mitchell, replacing the government's proposed one year with and two years without agreement periods with 18 months and three years respectively, passed by four votes to three with the support of the two SNP members and Labour's Mary Mulligan. ${ }^{116}$

Gillan attributes this reversal for the government, despite its majority on the committee, to the influence of the CI and the Catholic Church. These groups, which were unrepresentative of "mainstream opinion in Scotland", were "highly successful in framing policy debate, elevating marriage as the 'gold standard' of family relationships in political discourse and embedding this key influencing message into cross-party consciousness". 117 This appears to have been particularly effective in relation to the committee given a combination of the personal religious backgrounds of the committee members and the particular religious make-up of their constituencies. ${ }^{118}$ A Labour colleague of Mulligan on the committee, Marlyn Glen, professed herself "totally shocked" that the government's position was rejected and that members allowed their personal beliefs, background and circumstances to determine their actions rather than a concern for the needs of particular families living in Scotland at the time. ${ }^{119}$

\section{THE CHAMBER}

When the Bill moved to Stage 3 in late 2005 the government tabled two amendments to reinstate the non-cohabitation periods originally proposed by the SLC in 1989 and consulted on by government no less than three times. The question of what weight to attach

111 Justice Committee Report, n. 108 above, para. 47-50.

112 OR col. 19233-4, 15 September 2005.

113 The Stage 2 debate can be found at Justice 1 Committee OR 2 November 2005, col. 2179.

114 The SNP's Bruce McFall joining Mitchell and the other SNP MSP, Stewart Stevenson abstaining, OR col. 2191-2.

115 The two SNP members being joined by Labour's Mary Mulligan, OR col. 2219-20.

116 Ibid.

117 Gillan, Influencing Family Policy, n. 45 above, p. 274.

118 A civil servant interviewed by Gillan was of the opinion that "Margaret Mitchell's amendment was pulled from the Christian Institute and the SNP . . Fergus Ewing and Brian Adam, they're quoting from the wee frees . . Mary Mulligan is a practising Catholic and I think there is a lot of Catholic MSPs, primarily West Coast and the minister was under a lot of pressure.": ibid. p. 104.

119 Gillan, Influencing Family Policy, n. 45 above, p. 103. 
to consultation responses and the proper relationship between parliamentary committees and government were key issues raised by those opposed to the reforms.

Mary Mulligan made explicit reference to the numerically overwhelming opposition from consultation respondents, without apparent concern for the fact that many of these responses were near identical, rarely showed evidence of their author having seen the consultation papers, and were overwhelmingly generated by a single lobby group. ${ }^{120}$ As noted above, this was countered by the observation that the committee's amendments, drawn up in light of its call for evidence, had not been subject to any consultation process. ${ }^{121}$ Murdo Fraser complained that the government was, not for the first time, seeking to overturn a committee's carefully considered amendments and was "riding roughshod" over the aspirations for consensus and participation. ${ }^{122}$ However, the strength of this argument was challenged by the Deputy Justice Minister, Hugh Henry, who pointed out that if amendments made at Stage 2 should not be challenged at Stage 3 then there was no point in having a Stage 3 and also by the fact that Fraser's Conservative group itself frequently opposed Committee determinations in Stage 3 debates. ${ }^{123}$

When put to the vote, the Labour/LibDem coalition government succeeded in reinstating its time periods with only a handful of its own MSPs dissenting. ${ }^{124}$ The amendment to reduce the period without consent from five to two years passed by 91 votes to 34 while the reduction from two to one year with consent was passed by 93 to $31 .{ }^{125} \mathrm{On}$ the final vote on the entire Bill the government prevailed by 104 votes to 12 .

Despite this emphatic result, those forces opposed to progressive reform were not left without gain. Although these groups ultimately failed to control the specific legislative outcome, they succeeded in reframing the policy debate, most notably by shifting the debate from modernisation of the law to marriage as the "gold standard".126

At the outset of the Stage 3 debate the minister announced additional government funding of $£, 300,000$ for family support services, a move which would perhaps allow some wavering MSPs to support reform. ${ }^{127}$ In contrast to the earlier declared focus on the interests of children and on modernising the law, the minister was now at pains to recognise the "special status" of marriage and acknowledge divorce as "always a sensitive issue" which for many people touched "on their core beliefs about the sanctity of marriage and its importance as one of the principal building blocks of society." 28 While the government would not undermine marriage, the minister insisted that divorce law had to address the needs of particular families when a marriage ended in separation, especially in the interests of children.

The most commonly asserted principle among those opposed to reform was not modernisation or the interests of children but the importance of marriage as an institution. Murdo Fraser openly stated that his test was whether the Bill supported marriage and

120 OR col. 21772.

121 See text at n. 107 above.

122 OR col. 21776.

123 OR col. 21783

124 OR col. 21786-92 and 21947-9. Labour and the LibDems applied the party whip while the other parties allowed a free vote, Gillan, Influencing Family Policy, n. 45 above, p. 136.

125 On each vote four Labour and one LibDem MSP joined all Conservative and a number of SNP MSPs in opposing the reduction, OR col. 21788-92.

126 Gillan, Influencing Family Policy, n. 45 above, p. 144.

127 Supposedly over and above the existing annual support of $£, 630,000$ and the extra $£, 500,000$ provided "this year and last", OR col. 21765.

128 OR col. 21764 
couples staying together ${ }^{129}$ while others referred to marriage as the "gold standard" of adult relationships. ${ }^{130}$ Even those who most strongly supported reform, such as Green Party MSP Patrick Harvie, insisted that he had "always valued" marriage and had never "criticised the institution of marriage or proposed some way of undermining it". ${ }^{131}$

In both the committee and in the Parliament as a whole it is clear that strong feelings were engaged by the proposals, reflecting both personally held beliefs on the part of MSPs and concern at the reaction to reform expressed by particular interest groups. The evidence here confirms Gillan's conclusion from her study of the progress of the Family Law (Scotland) Bill as a whole, where she finds that although "faith groups" had a significant influence on the terms of the debate they failed in their attempt to control Parliament.

\section{Conclusion}

Examination of this particular extended law reform process informs consideration not only of the proper relationship between law commissions, executives and parliaments but also the value of consultation exercises. The effort involved in conducting, considering and responding to several consultations, only to arrive back at the "modest" proposal recommended by the SLC some 17 years previously, appears disproportionate. Devolution, with its aspirations for accessibility and participation, can, as we have seen, increase the effort involved in even modest law reform without contributing a great deal in terms of outcome.

Given the greater openness and accessibility of government and Parliament following devolution, and the problems of repeated consultation, it might be argued that the important role played by the SLC in keeping a focus on Scottish law reform in the past is no longer necessary. ${ }^{132}$ Abolition is not unthinkable ${ }^{133}$ but, given the (justifiably) very high regard that informed commentators have for the quality of the SLC's work and the combination of politicians' vulnerability to lobbying and the tendency of government to regulate so many areas of our lives, the role of the SLC may be viewed as more, not less, important in a country where politicians have more time to legislate. ${ }^{134}$ Although not impervious to criticism, commissioners cannot be lobbied or targeted in the way ministers, and even more so, particular MSPs, can. The time spent on consultation by the SLC does appear to influence, and perhaps improve, law reform proposals, with the caveat that the SLC should be careful not to necessarily give "the public" what it wants. ${ }^{135}$

The Scottish government was right to consult in 1999, given the 10 years which had passed since the SLC report, the change of UK government and the onset of devolution, but serious doubt must exist over the appropriateness of consulting a further twice before the production of the Bill in 2005. The government's commitment to the SLC's proposals was clear following the 1999 consultation and there was no new factor thereafter to justify inviting views again in 2000 nor, other than political expediency, in 2004. The drawn-out process was a waste of resources for government and respondents and tended to favour

129 OR col. 21932. See also e.g. SNP MSP Fergus Ewing at col. 21774.

130 Stewart Stevenson, OR col. 21769.

131 OR col. 21940 and 21777-8. Harvie asserted that "locking people into relationships when they have gone wrong" would hardly enhance the status of marriage.

132 For a wide-ranging attack on commissions in general, see A Samuels "The Law Commission: do we really need it?" (1986) NLJ 747.

133 Canada abolished its Law Commission in 2006, Brotchie, "Scottish Law Commission", n. 14 above, p. 34 , fn. 23.

134 Hope, "Do we still need a Scottish Law Commission?", n. 14 above.

135 In contrast, Lord Hope notes with approval the "widespread appreciation throughout Scotland of the close harmony which has been achieved between what the Commission does and what the public wants", "Do we still need a Scottish Law Commission?", n. 14 above, p. 26. 
well-resourced usual suspects: there is little evidence that the government consultations attracted responses from those who might fail to respond to an SLC consultation. ${ }^{136}$

Although there was some delay and a change in emphasis of rhetoric, the government was able to remain focused on improving the legal response to those whose marriage had broken down. No less a figure than Lord Hope of Craighead has stated that "[c]redit must go to the [Scottish government] for not finding itself too busy or too afraid to get on with this task" of producing a modern regime of family law. 137

The creation of the Parliament's committee system offered a new opportunity for interested parties to attempt to influence policy. It is, however, difficult to discern any new information arising from the Justice 1 committee's call for evidence on the government's proposed reforms which might justify the expenditure of effort on the part of those expected to respond. While it is refreshing that legislators resist toeing the party line, the comments by those working most closely with these particular MSPs that this was done on the basis of their individual religious affiliations and in light of the supposed religious make-up of their constituencies rather than in the interests of individual families in difficulty is worrying.

Devolution has meant that both government and more especially Parliament (whether as individual MSPs or in committee) have been more open to, and engaged by, interest groups than was the case in relation to Scottish legislation at Westminster. What there is no evidence of is achievement of what Arter calls the aspiration to engage with the "authentic voice of Scotland". 138 The question of what value to attach to particular views, especially when presented by powerful media-savvy and well-resourced minority groups, remains unresolved. What is clear is that such groups can have a significant effect on the law reform process with, at least in this case, little discernible impact on the eventual outcome. In that respect, the resources expended on multiple consultation may be viewed as a significant cost of devolution.

136 In particular, service providers, whether in the voluntary, public or private sector, may have "opportunity costs" when their resources are expended not in their central role as support worker or academic or solicitor but on presenting the same arguments and evidence several times in repeated consultation processes, see e.g. North "Law reform", n. 20 above, pp. 344-6.

137 Hope, "Do we still need a Scottish Law Commission?", n. 14 above, p. 25, my emphasis.

138 Arter, "From 'spectator democracy' ...", n. 13 above. 
